\title{
Patent urachus
}

INSERM

\section{Source}

INSERM. (1999). Orphanet: an online rare disease and orphan drug data base. $\underline{\text { Patent }}$ urachus. ORPHA:431341

Patent urachus is a type of cong enital urachal anomaly (see this term) characterized by a persistent communication between the bladder and the umbilicus, secondary to non occlusion of the urachal lumen, manifesting as clear drainage from the umbilicus. 